\title{
RISE AND DECLINE OF CHINCHORRO SACRED LANDSCAPES ALONG THE HYPERARID COAST OF THE ATACAMA DESERT*
}

\section{AUGE Y DECADENCIA DEL PAISAJE SAGRADO DE LOS CHINCHORRO EN LA COSTA HIPERÁRIDA DEL DESIERTO DE ATACAMA}

\author{
Calogero M. Santoro ${ }^{1,2 *}$, Marcelo M. Rivadeneira ${ }^{3}$ Claudio Latorre $^{4,5}$, \\ Francisco Rothhammer ${ }^{1,2,6}$ and Vivien G. Standen ${ }^{7}$
}

\begin{abstract}
The study of complex funerary ritual development among hunters and gatherers societies should take into account how people made up for the continuity of their social system without the support of centralized organizations. This research integrates cultural and natural factors to explore how the Chinchorro carried on with their way of life isolated at geographically restricted perennial river mouths with fresh water along the Atacama Desert in the Pacific coast of South America. Within these rather crowded settlings, they created and maintained a social system catalyzed by a complex funerary tradition, embodied by a unique funerary ideological discourse that resulted in the creation of a sacred landscape or "spiritscape". We argue that the extreme hyperaridity of the coastal Atacama Desert $\left(21^{\circ}-17.30^{\circ} \mathrm{S}\right)$, and the extraordinary biomass production of the marine littoral constituted a fundamental milieu for the maintenance of their long-term social system. The Chinchorro belief system lasted for several millennia $(8,000-4,000 \mathrm{BP})$, but new ways of life and burial practices followed major changes in the coastal ecosystem they relied on, which would have influenced how the "old tradition" was manifested over time. Conversely, we sustain that these natural "constraints" faced by the Chinchorro along the coast of the Atacama Desert, were influential, in the course of their history or the way they socially organized themselves.

Key words: Chinchorro spiritscape, sacred landscape, hyperaridity, coastal Atacama Desert.
\end{abstract}

Es conveniente que el estudio de rituales funerarios complejos desarrollados por colectividades de cazadores recolectores considere la forma como éstas lograron mantener un sistema social sin la ayuda de organizaciones sociales centralizadas. Este estudio integra factores culturales y naturales para explorar cómo los Chinchorro manejaron su sistema de vida en localidades aisladas y geográficamente circunscritas a un pequeño número de desembocaduras de quebradas con agua fresca y algunas aguadas ubicadas a lo largo de la costa del Desierto de Atacama en América del Sur. En estos asentamientos, más bien sobrepoblados, los Chinchorro crearon y mantuvieron un sistema social caracterizado por una compleja tradición funeraria, representada por un sistema ideológico único que resultó en la creación de un paisaje sagrado o espiritual. Argumentamos que las condiciones de extrema hiperaridez de la costa del Desierto de Atacama $\left(21^{\circ}\right.$ - $\left.17.30^{\circ} S\right)$ y la extraordinaria producción de biomasa del litoral marítimo constituyeron pilares fundamentales para la mantención a largo plazo de su sistema social. El sistema de creencias de los Chinchorro se mantuvo por varios milenios (8.000-4.000 a.p.), pero nuevas formas de vida y prácticas funerarias fueron experimentadas después que el ecosistema costero del que dependían sufriera cambios mayorers, que parecen haber dificultado la reproducción de la "vieja tradición". Consecuentemente, concluimos que los constreñimientos naturales de la costa del Desierto de Atacama fueron influyentes en el curso de la historia y la manera como los Chinchorro se organizaron socialmente.

Palabras claves: Chinchorro, paisaje espiritual, paisaje sagrado, hiperaridez, costa desierto de Atacama.

* Artículo proyecto ECOS-CONICYT Dinámicas culturales en el Área Centro Sur Andina. Código C06H04 y PICS 4796.

1 Instituto de Alta Investigación, Universidad de Tarapacá, Antofagasta 1520, Arica, Chile, calogero_santoro@yahoo.com

2 Centro de Investigaciones del Hombre en el Desierto, Avda. General Velásquez 1775, of 403, Arica, Chile. *Corresponding author

3 Centro de Estudios Avanzados en Zonas Áridas (CEAZA) \& Universidad Católica del Norte, Larrondo 1281, Coquimbo, Chile, marcelo.rivadeneira@ceaza.cl

4 Center for Advanced Studies in Ecology \& Biodiversity (CASEB) \& Departamento Ecología, Pontificia Universidad Católica de Chile, Alameda 340, Santiago, Chile, clatorre@bio.puc.cl

5 Institute of Ecology \& Biodiversity (IEB), Casilla 653, Santiago, Chile.

6 Programa de Genética Humana ICBM, Facultad de Medicina, Universidad de Chile, Avda. Independencia 1027, Santiago, Chile, frothham@med.uchile.cl

7 Departamento de Antropología, Universidad de Tarapacá, 18 de Septiembre 2222, Arica, Chile, vivien.standen@gmail.com 
Social and territorial circumscription among hunters and gatherers during the PleistoceneHolocene transition was a worldwide phenomenon. Nevertheless, the cultural effects of these processes on societies that colonized marginal and environmentally extreme landscapes remain poorly studied. This is the case of the Chinchorro, a mid-Holocene decentralized society that as coastal-marine huntergatherers, faced and learned to live in the Mars-like Atacama Desert extreme hyperarid coast of northern Chile (Drees et al. 2006).

The Chinchorro were a cultural tradition of hunters, fishermen, and gatherers that relied mostly on marine resources, complemented by some terrestrial ones, and whose extractive economy did not include animal and crop husbandry or any other form of cultivation. The archaeological background of these peoples shows that for approximately five millennia they maintained a social system that included a semi-sedentary settlement pattern centered around residential camps located along the few isolated mouths of perennial rivers (canyons) and springs that flowed into the Pacific within their territory (Figure 1) (Standen and Santoro 2004). Mobility was likely restricted to interior oases formed by isolated springs and rivers within hyperarid conditions, from where they obtained complementary resources (i.e. lithic raw material, which are absent on the coast; (Núñez 1975; Schiappacasse 1995; Schiappacasse and Niemeyer 1975), although no evidence exists for the introduction of obsidian, found only in the high Andes.

Thus, the Chinchorro mostly moved along the coast to maintain their social ties, and relations with other neighboring groups. It is possible that their social organization was based on kin-related groups integrated by several adults and children, both female and male, as signaled by the display of extended, multiple burials. Their mortuary system shows a wide variety of forms to treat the corpses of deceased people, which ranged from simple interment of a corpse wrapped in plant fiber mats to heavily modified corpses that were then artificially mummified (Allison et al. 1984; Arriaza 1994; Standen 1997). Although the Chinchorro did not invest much energy in domestic infrastructure in their camps (represented today by large shell middens), the recurrent use of the same place used both by the living and the dead created a unique landscape and associated "spiritscape" (Knapp and Ashmore 1999; McNiven 2003) and the possible sense of belonging to a particular community and territory; which are unparalleled along the Pacific coast of South America. The uniqueness of this "spiritscape" was favored by the high marine primary productivity of coastal northern Chile (Kaschner et al. 2008; Ortlieb et al. 2011), discussed below.

We argue that geographic and ecological conditions were influential in the development and maintenance of their cultural landscapes, embodied in complex and time consuming funerary procedures that included artificial mummification (AM) of human corpses buried close to or inside the living areas. The economy, technology, ideology, and mortuary practices of the Chinchorro endured for approximately four millennia (ca. 8,000-7,000 to 4,000-3,000 cal yrs BP or calibrated ${ }^{14} \mathrm{C}$ years before 1950) when the social and environmental constraints failed to provide the necessary life support for the reproduction of their traditional way of life (Marquet et al. 2012). As a consequence, new cultures and sacred landscapes arose, although still within a hunting and gathering marine social system.

Here, we analyze the cultural and natural factors behind the continuity and changes of the Chinchorro social system with its ideological discourse, based on the premise that even in the harshest environment such as the Atacama Desert, hunters, fishermen and gatherers found ways to "keep on going" (Ingold 2011:4) by reproducing their social system which was not exclusively devoted to subsistence procurement (Dillehay 2011; Gamble 1999; Winterhalder 1993). In other words, we expect to broaden the understanding of the conditions that allowed the Chinchorro to create, maintain, expand, and eventually abandon their cultural tradition.

\section{The Chinchorro Burial Practice}

The first studies of the Chinchorro (Skottsberg 1924; Uhle 1917, 1919a, b, 1922) did not consider social and environmental backgrounds for the occurrence of their society. Rather, the focus was on AM itself, which as a cultural prehistoric phenomenon has been recently highlighted as a conspicuous cultural phenomenon (Arriaza 1995a, b; Arriaza et al. 2012; Arriaza et al. 2008; Bittmann 1982; Bittmann and Munizaga 1976, 1979, 1980; Guillén 2004; Guillén 1995; Munizaga 1974; Núñez 1966, 1969; Standen 1991, 1997, 2011; Steele and Politis 2009; Van Hoesen and Arriaza 2011). Recently (Marquet et al. 2012) 
emphasized the importance of hyperarid conditions and past climate change coupled with social and environmental factors for the origin of AM.

Before inhumation, some corpses were drastically modified and transformed into a "new" artificially mummified being. Groups of collective interments were covered by reed mats, suggesting that the basic unit of the society was rooted in collectiveness and sharing. In contrast, post Chinchorro funerary patterns emphasized individual interments with particular garments and offerings (Standen et al. 2004). Based on cultural archaeological material from Camarones 14, Schiappacasse and Niemeyer (1984), suggested an Andean origin of the Chinchorro people, precursory signs of their mortuary rituals have been found at Acha 3, along the coast of Arica, and at Quebrada los Burros in southernmost Peru, both dated around 10,000 to 9,000 cal yrs BP (Delabarde et al. 2009; Lavallée et al. 2011; Standen and Santoro 2004). Nevertheless, as will be discussed later, recent ancient mtDNA evidence actually endorses an highland origin (Manríquez et al. 2011).

Radiocarbon dating has established that of all the Chinchorro funerary rituals, black mummies are the oldest and most complex (7,000 to 4,800 cal yrs BP), and the earliest evidence of AM (child mummies) comes from Camarones (Arriaza and Standen 2002:29). Corpses were skinned, defleshed and dismembered; the abdominal organs and the brain were removed and, in some cases, the thoracic cavity was heat-dried using glowing coals and ashes. The skeleton was reassembled and reinforced with long wooden sticks tied with plant fiber strips. This "new body structure" was modeled with grey clay. Skin, possibly of the same individual, was refitted on the body and coated with a black paste possibly made with manganese. Sexual and facial characteristics were modeled and a short black-hair wig was attached to the back to the head. This pattern is mostly restricted to the Camarones - Azapa region (Figure 1).

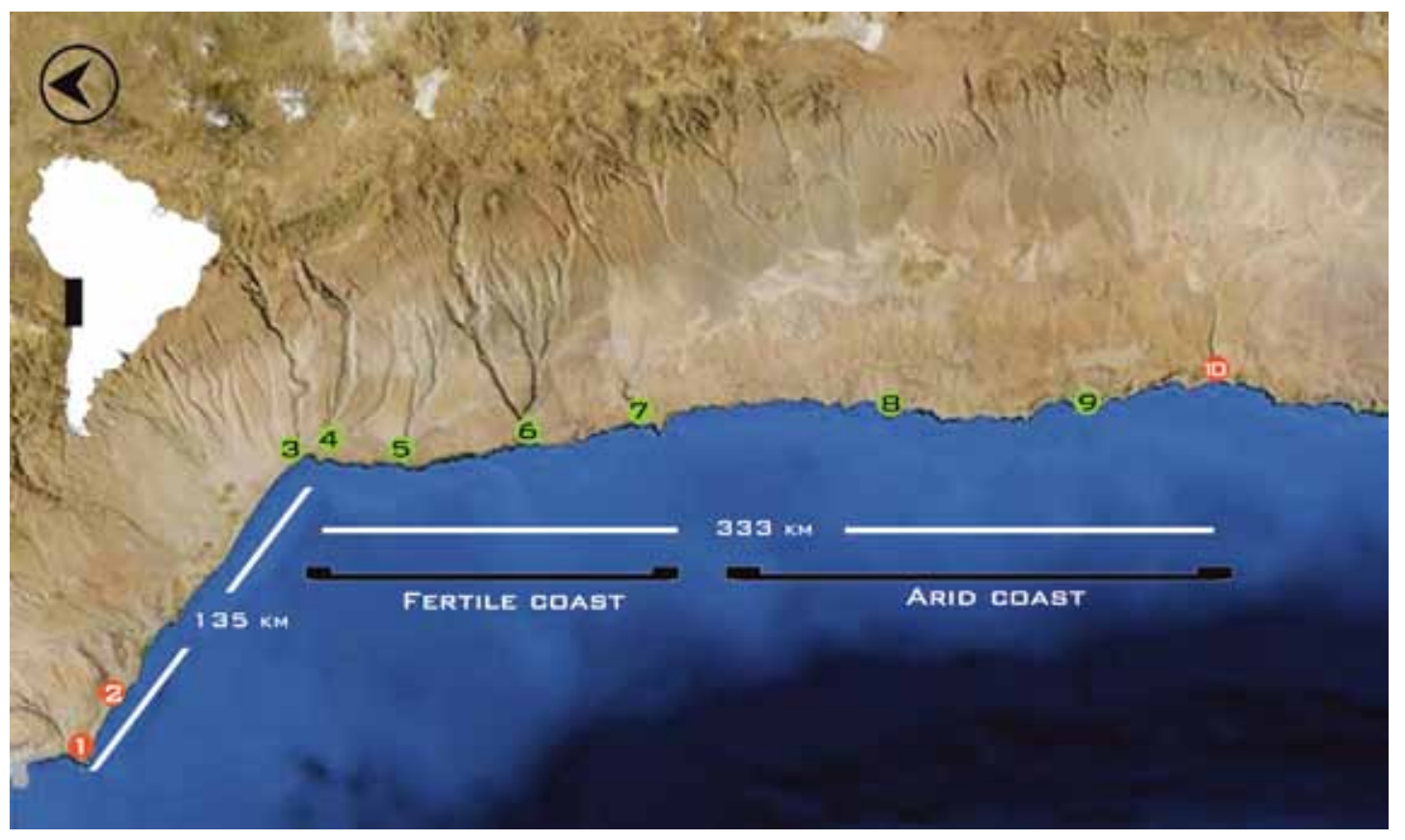

Figure 1. Territorial distribution of Chinchorro camps located along the few perennial river mouths (canyons) and springs that flowed into the Pacific: (1) Yara (spring), Kilómetro 4 (spring), Viña del Mar; (2) Los Burros (spring); (3) Macarena (Lluta); (4) Chinchorro-Arica (Azapa); (5) Caleta Vitor (Chaca); (6) Camarones; (7) Pisagua (Camiña); (8) Bajo Molle (spring); 9 Punta Patillo (spring); (10) El Loa.

Distribución territorial de sitios Chinchorro a lo largo de un número limitado de desembocaduras, quebradas y aguadas que fluyen en el Pacífico: (1) Yara (aguada), Kilómetro 4 (aguada), Viña del Mar; (2) Los Burros (spring); (3) Macarena (Lluta); (4) Chinchorro-Arica (Azapa); (5) Caleta Vitor (Chaca); (6) Camarones; (7) Pisagua (Camiña); (8) Bajo Molle (aguada); 9 Punta Patillo (aguada); (10) El Loa. 
Red mummies appeared at $~ 5,000$ cal yrs BP but did not completely replace the black mummy practice (Table 1). In this case, organs and several muscles were removed by making incisions in the shoulders, groin, knees, and ankles. The head was cut from the body and the brain removed. The body cavities were dried with glowing coals and ashes. Wooden thin poles (less than $3 \mathrm{~cm}$ of diameter) were introduced under the skin through the arms, legs, and spine to rigidify and provide the body with a structure. Body cavities and the head were then stuffed with sea bird feathers (pelicans, seagulls), different soil matters, and camelid fiber. A long, black human hair wig ( $\sim 60$ centimeters long) was attached. A black paste (elaborated using manganese and other elements) covered the face and the head to secure the wig. Facial characteristics were modeled. Incisions made in different parts of the body were sown using threads of human hair. The body was entirely covered with a red color paste (Arriaza and Standen 2002). This kind of transformation is recorded from Yara to Punta Patillo (Figure 1).

Alternatively, other procedures were added at later stages such as bandages made out of strings of leather or plant fiber, cordage and beach sand coating (Arriaza and Standen 2002). The bandaged mummies are basically a variation of the red ones, as the skin was reattached in the form of bandages and colored red. The sand-coated mummies correspond to naturally dried bodies covered with sand and which (Uhle 1917, 1919a, b) described as "mud-coated" mummies. Mummies such as these were recently discovered at Colon 10, a late Archaic funerary site located in the historical district of downtown Arica (Arriaza 1994, 1995a; Arriaza et al. 2005; Bird 1943; Santoro et al. 2005; Santoro et al. 2010; Standen 1997; Uhle 1974).

\section{Roots, Territorial and Social Boundaries}

By the end of the Pleistocene (ca 15,000-10,500 cal years B.P.), all the major landmasses had been colonized by humans, and as hunting gathering was the only form of social organization, the possibilities to maintain settlement systems in permanent movement became increasingly reduced (Flannery 1986). Colonized during that time, South America was also subject to processes of circumscription early in the Holocene (ca. 11,000-10,000 years cal BP; (Dillehay 2011; Dillehay et al. 2003), including marginal habitats with extreme hyperarid climate conditions such as the Atacama Desert (Grosjean et al. 2005a, b; Santoro et al. 2011; Steele et al. 2000; Steele and Politis 2009).

Human colonization of coastal northern Chile Atacama began by 10,000 to 9,000 cal BP and may have stemmed from earlier coastal groups found in Ecuador, and northern, central and southern Peru (Arriaza 1995a; Chauchat and Pelegrin 2003; de France and Umire 2004; Dillehay et al. 2012; Lavallée et al. 1999; Lavallée et al. 2011; Manríquez et al. 2011; Núñez and Santoro 2011; Rivera 1995; Rothhammer and Dillehay 2009; Sandweiss 2003; Sandweiss et al. 1998; Standen and Santoro 2004; Stothert et al. 2003). Current craniometrical data and genetic mtDNA evidence (Manríquez et al. 2011; Rothhammer et al. 2009) has revealed that the skeletal material uncovered at the Acha archaic site (10,000-9,000 BP) -where cultural roots of the Chinchorro have been found-, are related to an early coastal migration. In contrast, skeletal remains from Camarones 14 site $(8,000-7,000$ BP; Figure 1) seem to be more closely related to a highland migration, an idea first proposed by Schiappacasse and Niemeyer (Schiappacasse and

Table 1. Chronological distribution of principal artificial mummification procedures.

Distribución cronológica de los principales procedimientos de momificación artificial.

\begin{tabular}{lcc}
\hline & $\begin{array}{c}\text { Chinchorro Early } \\
\text { Archaic phase } \\
7,000-5,000\end{array}$ & $\begin{array}{c}\text { Chinchorro Middle to } \\
\text { Late Archaic Phase } \\
5,000-4,400\end{array}$ \\
\hline Baby high complex black mummy & $\mathrm{X}$ & \\
Baby median complexity AM & $\mathrm{X}$ & $\mathrm{X}$ \\
Adult and sub adult high complex black mummy & & $\mathrm{X}$ \\
Adult median complexity AM & & $\mathrm{X}$ \\
All ages, including fetuses, high complex Red style & $\mathrm{X}$ & $\mathrm{X}$ \\
Adult \& juvenile median complexity plastered style & & \\
All ages low complex natural mummification & & \\
\hline
\end{tabular}


Niemeyer 1984) based on cultural archaeological material from Camarones 14.

The geographic origin of the Chinchorro people, whether from the north coast or from the highland, does not imply that the mortuary practices were allocthonous. After their arrival on the coast, the Chinchorro could have developed complex and diverse funerary procedures as a result of experiencing the barrenness of the territory (Marquet et al. 2012). Moreover, non-metric dental traits from Yara individuals, and from other sites in the coast of Ilo zone, show certain biological similarities with Chinchorro people located in northern Chile (Rasmussen 1998:85), indicating that some groups did not remain isolated and un-communicated.

According to Arriaza et al. (Arriaza et al. 2005), this funerary tradition began at the mouth of the Camarones valley (Figure 1), from where it expanded to the north and south. By the end of the Chinchorro cultural tradition (ca. 4,000 - 3,000 BP) the geographic distribution of AM encompassed a coastal fringe of $\sim 500 \mathrm{~km}$ (293 miles) from the Ilo $\left(21^{\circ} \mathrm{S}\right)$ zone in southern Peru to the El Loa canyon $\left(\sim 17.30^{\circ} \mathrm{S}\right)$ in northern Chile. This coastal fringe is interrupted by the mouth of 10 canyons that deliver perennial fresh water: Osmore, Locumba, Sama, Caplina, Lluta, Azapa, Vítor, Camarones, Camiña, and El Loa. No archaeological evidence of Chinchorro AM, however, has been reported for Locumba, Sama, Caplina, and Vitor. This may be due to sampling problems and poses a challenge for future research. Aside from rivers, conspicuous point springs that used to or even still emerge from the Coastal Cordillera (Núñez and Varela 1967) were also selected by the Chinchorro (i.e. Yara, Los Burros, Quiani, Punta Pichalo, Bajo Molle, Punta Patillo, Figure 1).

The Chinchorro, as hunter gatherers, do not show the economic pattern of hunting for small and/or large games, plant recollection and highly mobile residence (Dillehay 2011). In contrast, they were highly territorial foragers, subsisting on Pacific coast marine resources that they mastered with specialized maritime technology, which reduced the stress of the otherwise hyperaridity of the Atacama Desert. The coastal open settlement corresponds to residential rather permanent camps that formed extensive shell middens covering several square kilometers, which are locally known archaeologically as conchales (shell middens). These settlements are located above the fluctuation of the sea-level and shoreline occurred throughout the Holocene, which are described below.

Between the zone of Ilo and the El Loa river mouth it is possible to distinguish three physiographic zones related to the origin and expansion of Chinchorro societies. The core area corresponds to the segment made up of five river valleys (between Lluta and Camiña Figure 1) whose mouths were partially covered with totora (reed, Scirpus sp.), a key element for the Chinchorro burial bundle and domestic ware (Standen 2003). This section is also characterized by a littoral zone with almost no exposed coastal platform as the Coastal Cordillera emerges abruptly from the Pacific (Figure 2), and lomas vegetation is reduced to some shrubs, cactuses and tillandsiales (Latorre et al. 2011), specialized communities that live off fog moisture and almost no rainfall. It was here where the complex funerary behavior started to be practiced, 8,000 - 7,000 BP, and where all the different stages of this practice were experimented up to $4,000 \mathrm{BP}$. In contrast, a wide exposed continental platform extends north of the Lluta valley and an increase in local rainfall produces complex lomas vegetation, which complemented the marine diet of coastal hunting gathering (Latorre et al. 2011; Rasmussen 1998:109). Apart from the early archaic pre-Chinchorro features found at Los Burros (Delabarde et al. 2009; Lavallée et al. 2011), "it has been difficult to locate documented examples of Chinchorro-style burial sites" (Rasmussen 1998:78). Studies by Wise (Wise 1990, 1995), Rasmussen (Rasmussen 1998) and Umire (Umire 2009) show that sites Yara, Villa del Mar, Kilómetro 4, and Carrizal 4 dated between 8,000 to $5,000 \mathrm{BP}$ in the Ilo zone, contain certain Chinchorro funerary traits (Umire 2009). This includes clay masks, and application of ochre (Villa del Mar; Rasmussen 1998; Wise 1995); while at the collective burial of Kilómetro 4, close to domestic areas, individuals in extended positions were covered with layers of reed mat, and some bones were wrapped in the same material (Wise 1999); a pattern also found in Carrizal (Wise 1997). Yara, which started to be occupied $\sim 8,000$ but more intensively around $5,000 \mathrm{BP}$, has yielded convincing Chinchorro traits, including ochre application, wrapped bones and wooden poles attached to long bones. This evidence made Rasmussen (Rasmussen 1998:76) state that "the Chinchorro were living in Ilo, Peru", confirming previous estimations (Allison et al. 1984; Arriaza, Allison, Focacci et al. 1984; Wise 1995). 


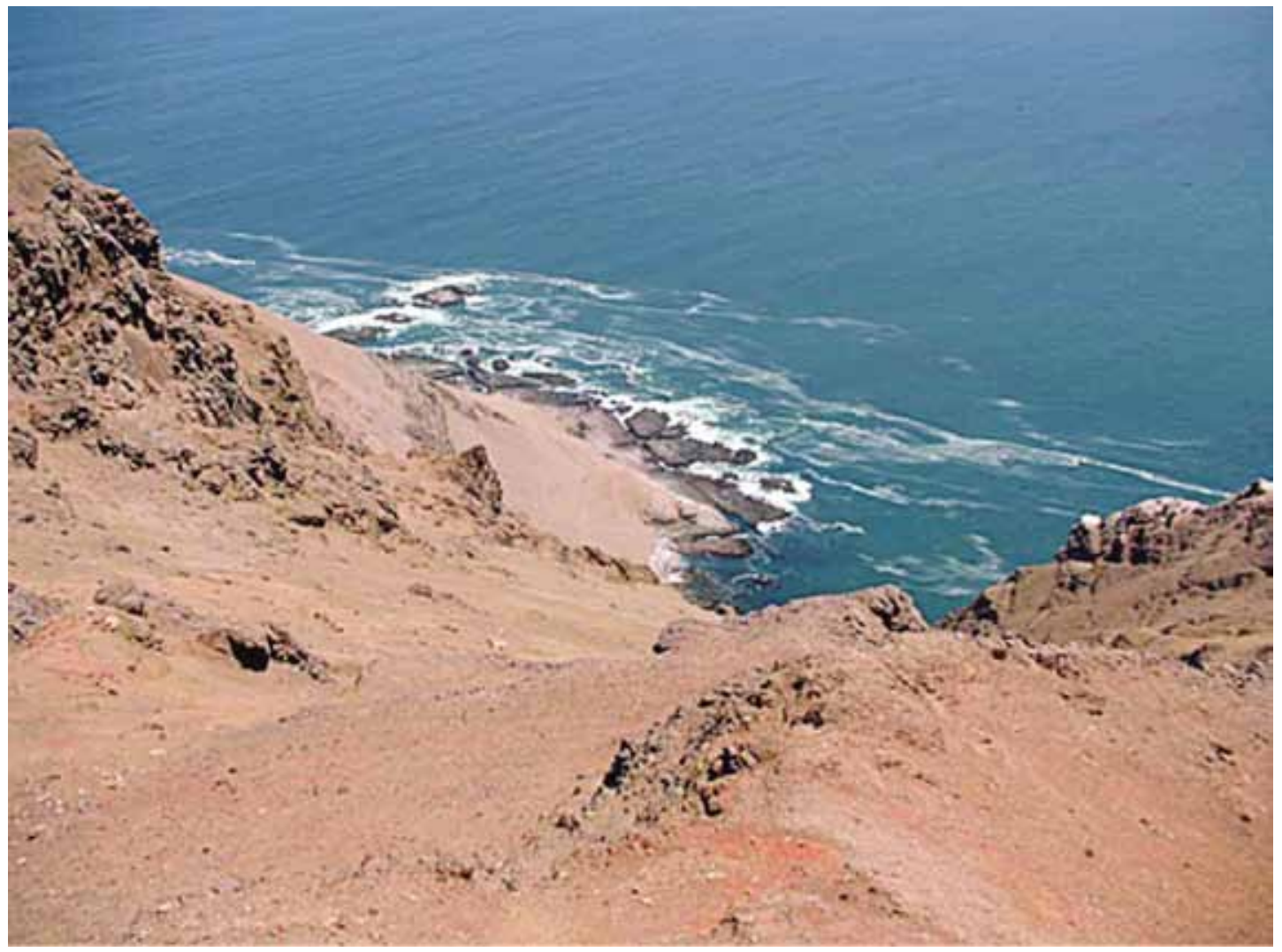

Figure 2. The Coastal escarpment emerges abruptly from the Pacific coast with almost no continental platform and no vegetation. Escarpe costero abrupto sobre la costa del Pacífico, con mínima plataforma continental, sin vegetación.

Yara collective burials also show evidence of other funerary features not seen in northern Chile (i.e. adults surrounded by children's heads, and stone around adults' heads), which make reference to other kinds of funerary rituals (Rasmussen 1998; Umire 2009). The preservation of the remains makes the evidence of fully artificially mummified bodies opaque, but the presence of wooden sticks attached to long bones is an unequivocal feature of the drastic transformation of corpses started with the earlier "black mummy style" in Arica. It is important to note that Chinchorro traits in the Ilo zone were mixed with other burial rituals used exclusively by the people that inhabited those locations, and which may have been introduced during the later phase of the Chinchorro.

South of Camiña until El Loa there are no perennial rivers along the Pacific littoral, mostly due to a reduction in the amount of rainfall along western Andes, and the interruption of that runoff by the a large endorrheic basin (Pampa del Tamarugal, $\sim 20-30 \mathrm{~km}$ from the coast) where complementary floral and faunal resources as well as raw material for lithic artifacts were available for coastal populations. Temporary camps, such as those of Tiliviche and Aragón, were established at inland oases some 20 to $30 \mathrm{~km}$ from the coast (Núñez 1986; Núñez and Moragas 1977-78; Núñez and Zlatar 1976). The absence of runoff merging into the Pacific is compensated by an increase in precipitation and fog moisture, which is intercepted by the Coastal Escarpment.

As in the northern section, this southern section contains evidence only of later expansion of the Chinchorro funerary tradition, which has been found in Bajo Molle, Los Verdes, and Punta Patillo, but the best evidence comes from the latter (Bittmann 1982; Bittmann and Munizaga 1976; Núñez 1965; Olmos and Sanhueza 1984; True and Núñez 1972). The remains, excavated by Ankel Nielsen during the 1940's, included burials of adults in extended dorsal position, face up, covered by reed mat and 
application of clay masks (Figure 3). The cemetery also included clay figurines (Figure 4). South of Patillo, Chinchorro features consist of application of red color and paste to cover the orbit of certain adult individuals found at Caleta Huelén 42 site, in the northern margin of the mouth of El Loa river (21 ${ }^{\circ}$ S; (Núñez and Santoro 2011:Figures 5a and $5 b)$. There are no valleys with permanent surface flow south of El Loa all the way to the mouth of the Copiapó river $\left(28^{\circ} \mathrm{S}\right)$. This extreme hyerparid coastline runs for $\sim 650 \mathrm{~km}$ (407 miles) where the lack of water is the product of decreased rainfall in the high Andes which in turns affects availability of runoff and groundwater resources along the coast (Latorre et al. 2005). Perhaps not surprisingly, the Chinchorro spiritscape did not expand into this territory; instead the Huentelauquén, another group coeval with the Chinchorro, developed a different landscape and social system, whose ideological world was channeled through other ritual performances, materialized by the use of "cogged-stones" and other geometric cut stones. These "cogged-stones" resemble those reported for coastal southern California, which have been interpreted as magical-religious artifacts (Jackson et al. 2011; Koerper and Cramer 2011; Koerper et al. 2006; Llagostera 1989; Llagostera et al. 1997; Núñez and Santoro 2011). The funerary procedures of the Huentelauquen people included impregnation of a red color substance as seen in the site El Hipódromo (Antofagasta). According to Agustín Llagostera (personal communication 2012), this feature led Juan Munizaga to think that the Chinchorro were

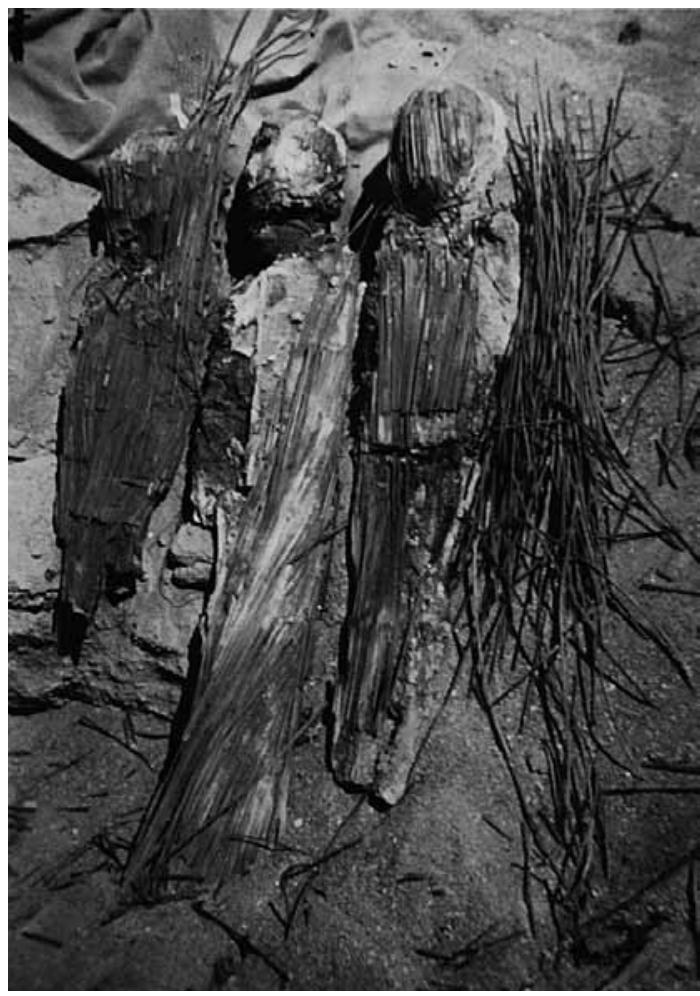

Figure 3. Chinchorro remains of adults covered by a reed mat and with a clay mask, excavated by Ankel Nielsen in Punta Patillo (photo courtesy of the American Museum of Natural History, New York, edited by Paola Salgado). Cuerpos de adultos Chinchorro cubiertos con estera de totora y máscara de arcilla, excavados por Ankel Nielsen en Punta Patillo (foto cortesía del American Museum of Natural History, de Nueva York, editada por Paola Salgado).

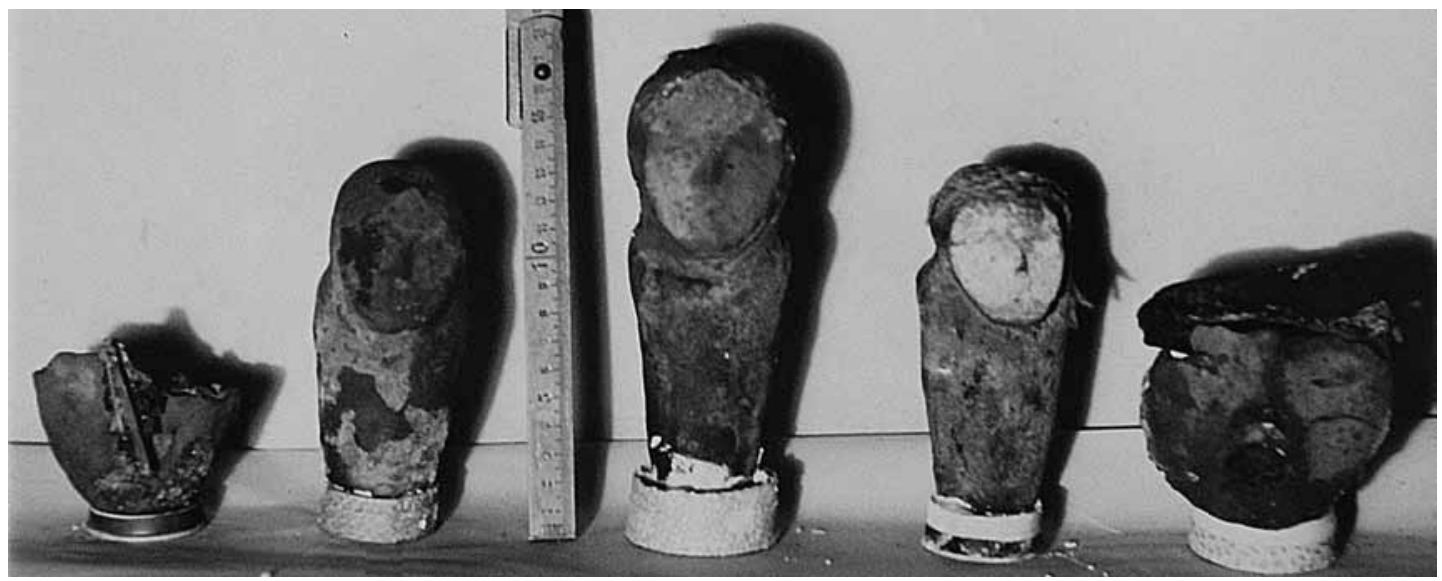

Figure 4. Group of clay figurines found together in Punta Patillo, excavated by Ankel Nielsen (photo courtesy of the American Museum of Natural History, New York, edited by Paola Salgado).

Conjunto de figurinas de arcilla encontradas en Punta Patillo, excavadas por Ankel Nielsen en Punta Patillo (foto cortesía del American Museum of Natural History, de Nueva York, editada por Paola Salgado). 


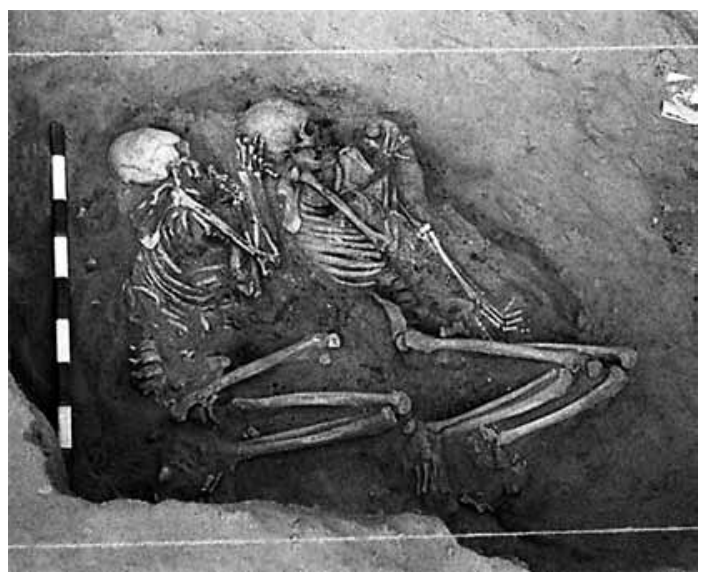

Figure 5. Undated human remains from burial at Los Canastos site, Antofagasta (female behind male), with vague evidence of Chinchorro ritual procedures (photo by an unknown photographer taken during the excavation of the site in 1974, led by Agustín Llagostera, who authorized its publication, edited by Paola Salgado).

Enterratorio, no datado, de dos individuos del sitio Los Canastos, Antofagasta (mujer detrás del hombre), con incierta evidencia de procedimientos rituales Chinchorro (foto de fotógrafo desconocido tomada durante la excavación del sitio en 1974 dirigida por Agustín Llagostera, quien autorizó su publicación, editada por Paola Salgado).

also living there (see also Arriaza 1995a), but this was a common feature in this region since the early Archaic throughout late periods. The most striking evidence comes from the site Los Canastos, and consists of two individuals, a female behind a male, lying on their left side with flexed lower extremities (Figure 5). The torso and the soil surface around them were spread with a mud coating, and covered with plant fiber mat and sea bird skins, which resemble the Chinchorro tradition. The offering, however, is a mix of late archaic and Chinchorro traits (aduja baskets, and net bags linked to sea food collecting, associated with the women, while the man offering was related to marine hunting, harpoons and darts, and pubic cover made out of plant fiber). Also, both individuals present annular head deformation (Llagostera 1983).

We maintain that the core of the Chinchorro territory was located at Lluta $\left(18^{\circ} 8^{\prime} S\right)$ and Punta Patillo (20 $\left.49^{\prime} \mathrm{S}\right)$. In the later phase, some Chinchorro key features made there way north up to Ilo (i.e. Yara site), and south down to El Loa. The Antofagasta case should be excluded from the Chinchorro social territorial landscape and spiritscape, because other ritual forms included features not seen in the Chinchorro tradition are present. It is possible that segments of the Chinchorro population reached these zones and became involved with people there to foster certain social activities including funerary practices, but this does not mean that the Chinchorro as a whole society were living there. Conversely, although there are no signs that the Chinchorro moved their residence permanently, they spread their social network and cultural pattern over $\sim 255$ $\mathrm{km}$ of coast, from the Lluta valley to Punta Patillo.

\section{Fresh Water and Marine Resources}

The sparse, pearl string-like distribution of fresh water resources was a key factor which the Chinchorro used intensively, instead of moving outside of these conspicuous coastal spots, to settle a larger territory for their subsistence procurements, as other groups living in hyperarid environments do. The availability of fresh water was linked to the prevalence of La Niña-like conditions during the mid-Holocene (Latorre et al. 2005; Rech et al. 2002). This implies a relatively steady rainy summer season on the high western slope of the Andes and increased ground water recharge (Rech et al. 2002). In these contrasting living spaces, the Chinchorro found crucial resources such as reed and cactus fruits. Because of hyper aridity, plant and game food, commonly consumed by hunters and gatherers even in coastal maritime environments, were rare in their economy and diet (Aufderheide et al. 1993; Schiappacasse and Niemeyer 1984).

In contrast, the Chinchorro had access to a bountiful Pacific coast favored by a rocky littoral and the upwelling of the Humboldt Current (Montecino and Lange 2009; Thiel et al. 2007), in which biomass abundance and richness includes mammals, fishes, mollusks, algae, and sea birds. Maximum marine primary productivity peaks at $\sim 18^{\circ} \mathrm{S}$ (Kaschner et al. 2008; Ortlieb et al. 2011), and present-day landings of artisanal fisheries in northern Chile $\left(18-21^{\circ} \mathrm{S}\right)$ are approximately two to three times higher than that observed for a similar geographic extension along southern Peru $\left(15-18^{\circ} \mathrm{S}\right.$ ) (Alfaro-Shigueto et al. 2010; SERNAPESCA 1999-2005). This highly productive and predictable seascape geographically coincides with the core of Chinchorro territory, and allowed them to intensify production through the development of a strong coastal-marine economy and long-term permanent settling. 
There is no continental coastal marine platform between the Lluta and Camiña valleys, thus walking from one river mouth to another along the littoral was highly unlikely. In general, the coastal platforms are narrow across the entire region (Figure 6). During the early phases of the Chinchorro, however, shoreline changes associated with a lower sea level stand may have favored the presence of wide platforms along the coast, as suggested by topographic analyses (Figure 6a). The lack of a specific Holocene sea level curve for the region prevents a more detailed evaluation of the impact of eustatic sea level changes on the inter-valley connectivity. However, reconstructions for other regions in Chile and Peru suggest a low sea level stand of several meters below present-day level until 8,000-7,000 years BP (Isla et al. 2012; Wells and Noller 1999). This sea level regression may have allowed the presence of marine platforms of moderate slope (i.e. $<25^{\circ}$, Figure 6 b), favoring travel of early Chinchorro populations along the coast. Between 6,000 to 5,000 years BP, sea level rose up to 5-6 $\mathrm{m}$ (Encinas et al. 2006), almost erasing marine platforms (i.e. slopes $>80^{\circ}$, Fig. 9b), thus reducing the possibility to walk through the littoral and increasing the chances of isolation among populations. The Chinchorro, however, selected for their living and interment areas at higher elevation, above these sea level and shoreline fluctuations.

Within these living circumstances the Chinchorro show higher degrees of pathologies, not common to hunter-gatherers living with a high mobility and small demography. The most frequent acute infectious diseases correspond to pneumonia, whereas chronic pathologies included periostitis, treponematosis, osteitis, parasitic infections, and signs of nutritional stress evidenced by orbital sieve and hypoplastic lines. They also suffered from arseniasis and occupational diseases like external auditory exostosis, and osteoarthrosis (Allison 1989; Arriaza 1995a;

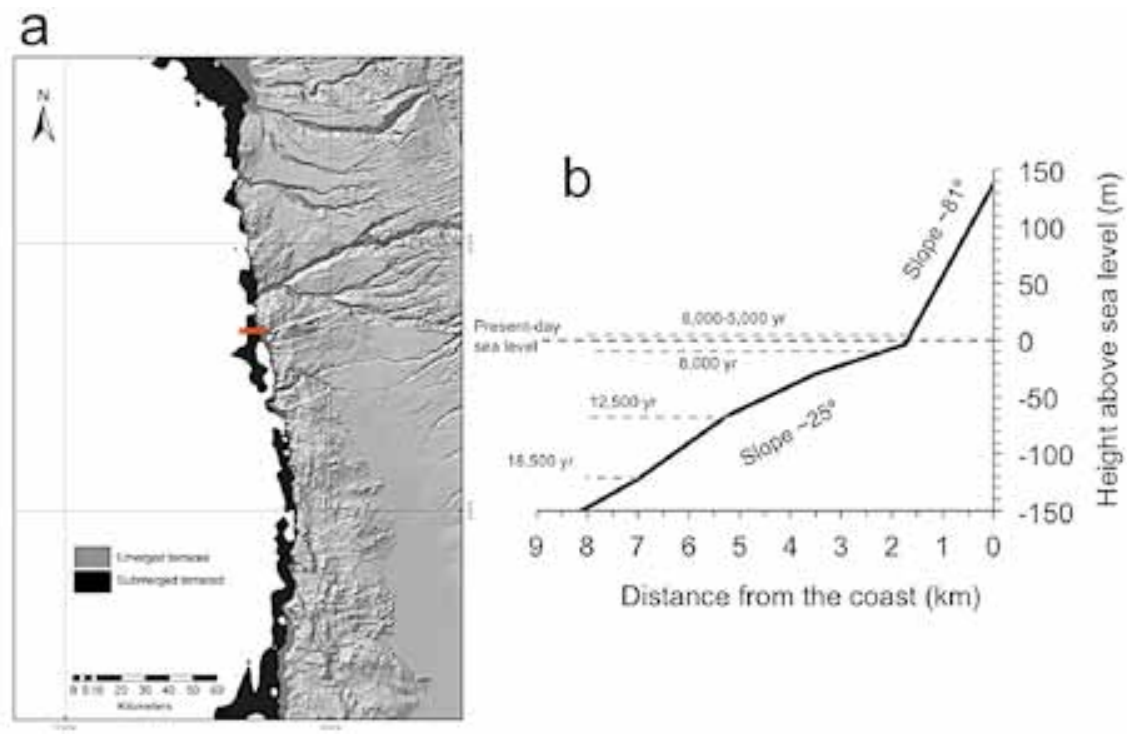

Figure 6. Potential connectivity across the northern coast of Chile during the Holocene, modulated by eustatic sea level changes: (a) connectivity is inferred by the width of marine terraces (defined as areas between 0-100 $\mathrm{m}$ above sea level). Submerged terraces were much more developed than today, allowing potential connections of canyons along the coast; (b) elevation profile for particular latitudinal section (red strip in "a") showing the presence of moderate slope marine terraces during low sea levels during the Pleistocene Holocene transition. Elevation data obtained from Global Multi-Resolution Topography (GMRT, Ryan et al. 2009). Holocene sea levels collected from several sources (Waelbroeck et al. 2002).

Potencial conectividad a través de la costa norte de Chile durante el Holoceno modulada por cambios eustáticos del nivel del mar: (a) conectividad inferida por el ancho de las terrazas marinas (definidas como áreas entre 0-100 m sobre el nivel del mar). Terrazas sumergidas eran mucho más desarrolladas que en la actualidad, permitiendo la conexión potencial de las quebradas a lo largo de la costa, (b) perfil de elevación de una sección latitudinal particular (franja roja en «a»), que muestra la presencia de terrazas marinas de pendiente moderada en épocas con niveles del mar más bajos durante la transición Pleistoceno Holoceno. Los datos de la elevación fueron obtenidos del Global Multi-Resolution Topography (GMRT, Ryan et al. 2009). Los niveles del mar durante el Holoceno fueron obtenidos de varias fuentes (Waelbroeck et al. 2002). 
Arriaza, Allison and Standen 1984; Aufderheide 2003; Aufderheide and Rodríguez-Martín 1998; Boston and Arriaza 2009; Byrne et al. 2010; Reinhard and Aufderheide 1990; Reinhard and Urban 2003; Standen 1991; Standen et al. 1984; Standen and Arriaza 1999, 2000a; Standen et al. 1997). This pathological profile, which clearly increased over time (Arriaza 1995a; Standen 2011; Standen et al. 1997), suggests long-term residence of all members of the Chinchorro nuclear social groups, rather than permanent residential mobility, which may amplify the possibilities for transmission of infectious diseases, along with the contamination of the recurrently used domestic spaces and the scarce sources of fresh water, facilitating the proliferation of bacteria, viruses, and parasites (Standen 2011). Moreover, postmortem manipulation of human corpses for evisceration and brain extraction linked to the operational sequence for AM may have also triggered the propagation of infectious diseases (Arriaza 1995a). Besides health condition and diseases, the Chinchorro experienced population growth within the same residential areas (Aufderheide et al. 1993).

The geomorphic and ecological circumstances experienced by the Chinchorro during the early to middle Holocene (ca. 9,500-5,000 cal years BP) changed and became more stressful in the midHolocene (5,000-4,000 years cal BP). The climatic, oceanographic, and ecological changes altered the traditional habitat managed by the Chinchorro. Besides the sea level transgression, major transformations occurred in the littoral ecosystem, as El Niño events increased in frequency and intensity after 5,000 years cal BP (Andrus et al. 2008; Chazen et al. 2009; Debret et al. 2009; Grosjean et al. 2007; Moy et al. 2002; Sandweiss et al. 2001; Williams et al. 2008). The transformation of the coastal marine ecology was also enhanced by a reduction in fresh water availability that affected the habitability of the Chinchorro crowded/overpopulated homeland (Draper 1973). Today, El Niño events increase the possibility of drought over the western central Andes (Grosjean et al. 2005a, b; Nester et al. 2007; Núñez et al. 2002; Santoro et al. 2011). The marine productivity in coastal environments, measured as the regional radiocarbon reservoir effect, experienced a noticeable drop (due to decreased upwelling of deep water) after 5,000 years cal BP across southern Peru and northern Chile (i.e.14-24 $4^{\circ}$, Figure 7a) (Ortlieb et al. 2011). Other paleoceanographic studies have yielded different trends (Mohtadi et al. 2004), but
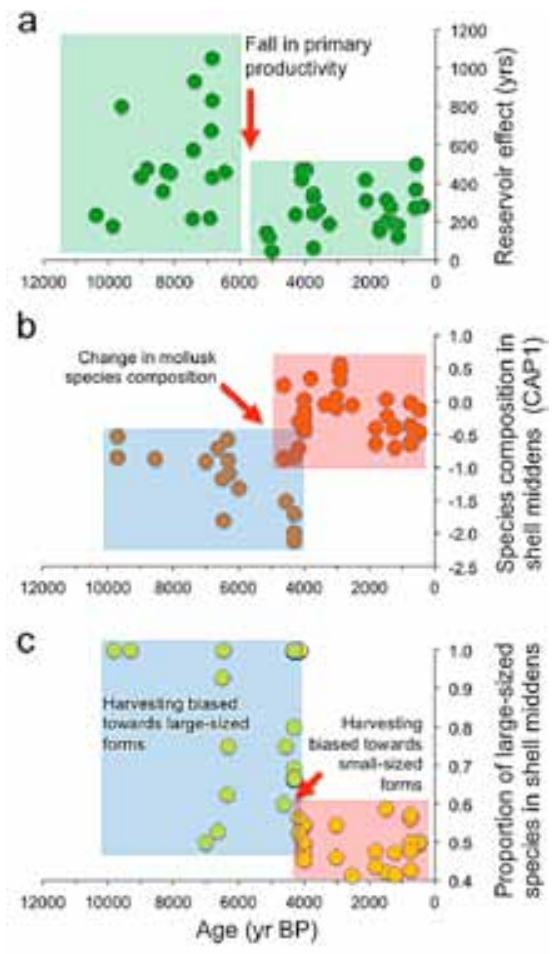

El Niño

Figure 7. Changes in the paleoceanographic and paleoecological conditions of marine coastal assemblages along central Perú and northern Chile during the Holocene: (a) primary productivity estimated as the reservoir effect $\left(14-21^{\circ} \mathrm{S}\right)$, data taken from Ortlieb et al. (2011), (b) changes in species composition in mollusk assemblages (bivalves and gastropods) in shell middens of central Peru and northern Chile $\left(12-31^{\circ} \mathrm{S}\right)$. Species composition measured as the first axis of a constrained analysis of principal coordinates (CAP, Anderson and Willis 2003) based on a matrix of 71 species and 29 shell middens, and (c) changes in proportion of large-sized mollusk species in shell middens. The cut-off level to define large ( $>45 \mathrm{~mm}$ ) and small forms $(\leq 45 \mathrm{~mm}$ ) corresponds to the median of the maximum shell length of 58 species. Shell midden data was compiled from an exhaustive literature survey combined with new samplings.

Cambios en las condiciones paleoceanográficas y paleoecológicas en ensambles marinos costeros a lo largo de la zona central de Perú y norte de Chile durante el Holoceno: (a) estimación de la productividad primaria como efecto reservorio $\left(14-21^{\circ} \mathrm{S}\right)$, datos tomados de Ortlieb et al. (2011), (b) cambios en la composición de especies en ensambles de moluscos (bivalvos y gastrópodos) en conchales del centro de Perú y norte de Chile $\left(12-31^{\circ} S\right)$. Composición de las especies medido a partir del primer eje de un análisis restringido de coordenadas principales (CAP, Anderson y Willis 2003), basado en una matriz de 71 especies y 29 conchales, y (c) cambios en la proporción de especies de moluscos de gran tamaño en conchales. El nivel de corte para definir las categorías de tamaños grande (> $45 \mathrm{~mm}$ ) y pequeño $(\leq 45 \mathrm{~mm})$ corresponde a la mediana de la longitud máxima de la valva de 58 especies. Los datos de los conchales fueron compilados a partir de una revisión bibliográfica exhaustiva combinada con nuevos muestreos. 
these more likely reflect oceanic rather than coastal conditions. A marked shift in the species composition of mollusks in shell middens of central Peru and northern Chile $\left(12-31^{\circ} \mathrm{S}\right)$ has been observed for the period between 4,500-4,000 years cal BP (Figure 7b), associated with the onset of El Niño and the collapse of the primary productivity. The timing of this transition is rather different from that indicated for mollusk assemblages of northern Peru (Sandweiss et al. 2001) bracketed around 5,800 to 3,000 years cal BP, suggesting that the transition was asynchronous along the coast of the Humboldt Current Ecosystem. The change in composition comprised a drastic reduction in the proportion of large-sized species harvested by people (Figure 7c), the abundance of which likely declined as a result of the environmental forcing, rather than overfishing (Rivadeneira et al. 2010). For example, before 4,000 cal years BP most of the species harvested (50-100\%) were large-sized forms, including Concholepas concholepas, Choromytilus chorus, Fissurella spp., and Mesodesma donacium; after $4,000 \mathrm{BP}$, the percentage of large-sized species drops to $40-60 \%$, implying a change in the subsistence strategy towards preferential harvesting of smaller species, such as Scurria spp., Chlorostoma spp. and Donax spp. The reduction in the availability of large-sized species may have implied increased fishing efforts, via longer and deeper diving excursions and a time-consuming gathering of more common but small-sized intertidal species (e.g. Scurria spp., Donax spp.) during the low tides (Llagostera 1982, 1983).

Coincidentally, during this epoch certain changes in subsistence strategies are noticeable, such as the shifting toward intensified fishing with a variety of new tools and technology such as the removable wooden harpoon head, fishhooks of different sizes and materials, stone weights for fishing nets, and fishing lines, which made marine extraction more efficient in terms of productivity (Bird 1943; Schiappacasse and Niemeyer 1984; Wise 1990). More intense use of terrestrial plant and game resources was not possible as seen elsewhere.

These transformations, however, seem to be opposed by population growth, as reflected by an increase in the quantity of cases of AM and the number of sites and radiocarbon dating toward the late Holocene (Williams et al. 2008). Population increase and reduction or changes in the traditional resources triggered population pressure and possibly enhanced competition among groups. Regional competition for resources (Wise 1990) seems to be signaled by an increase in interpersonal violence as shown by bone trauma, during the late phase of the Chinchorro. In some cases, interpersonal aggression resulted in death, a phenomenon not seen in early phases (Aufderheide et al. 1993; Standen and Arriaza 1999, 2000b). Moreover, food and water poisoning through arseniasis, a natural condition still present in the zone, affected population throughout the whole history of the Chinchorro, thus it may have also contributed to the apparent Chinchorro process of cultural transformation. Arsenic is very high in the natural water system $(1000 \mu \mathrm{g} / \mathrm{L})$ as well as in the food. For instance, Camarones arsenic level in the water is 100 times higher than accepted WHO recommendations, and considering its nocive effect of population (i.e. premature births, stillbirths, low birth weight, spontaneous abortions, high infant mortality, systemic organ damage and low red blood cell production made Arriaza and collaborators to suggest this problem as possible cause for the origin of AM, as a social response (Arriaza 2005; Boston and Arriaza 2009; Byrne et al. 2010). What we see is that the apparent stressful and conflicting social atmosphere and the transformation of natural conditions during the later phase of the Chinchorrro were associated with a diversification and an increase in AM procedures (Table 1), which means that besides the technological changes to intensify production people made effort to build on the ideological side and rituals of their social structure.

\section{Discussion and Conclusions}

The Chinchorro provides an excellent case study that sheds light on the diversity shown by ancient forager societies, and on the theoretical anthropological discussion with regard to the conditions, both social and ecological, that maintain a cultural system or trigger innovative processes that resulted in new behavioral patterns (Craig 2011). Contrasting archaeological, ecological, paleoecological, and oceanographic factors have been compiled to highlight some clues to understand how the Chinchorro foraging society maintained and transformed their way of life $(9,000-8,000$ to $4,000-3,000 \mathrm{yr} \mathrm{BP})$. The hyperaridity of the coastal Atacama Desert was not restrictive for Chinchorro social organizations, as they accommodated their everyday life to the sparse, pearl-string like distribution of fresh water 
spots along $\sim 500 \mathrm{~km}$ of coast from Ilo to El Loa (Figure 1). The Chinchorro flourished under the prevalence of La Niña-like conditions that help to maintain the 10 river mouths and springs documented here. There, they had the possibility to select from a bountiful marine coastal environment, a long and almost unlimited list of resources (Bird 1943; Schiappacasse and Niemeyer 1984; Wise 1990); they also managed with ingenious technologies to obtain the necessary resources for their everyday life. More importantly, combining these two natural contrasting conditions, they were able to support the leisure time needed for the creativity, experimentation and transmission involved in creating a unique cultural landscape (Ingold 2000, 2011), or "spirtscape" (McNiven 2003), signaled by complex funerary rituals that included AM applied to all the members of the social groups (Probst 2002). The "renovated bodies", along with other un-mummified corpses, were placed within or outside the domestic areas that were continuously used for several millennia. Like the Australian Aboriginal people and Torres Strait Islanders, the Chinchorro heavily relied on coastal marine resources, and likely saw themselves as a "Saltwater People" developing a rich and complex spiritual cosmology. This "spiritscape" helped them "spiritually manage and control their seas and ultimately orchestrate their seascapes" (McNiven 2003:329). The Chinchorro landscape and "spiritscape" can be archaeologically viewed through truly funerary areas, within or separated from the residential domains, uncommon among prehistoric hunters and gatherers. The "spiritscape" was gradually formed by adults, sub adults, children, and new born, both female and male, one next to or even on top of each other.

As living conditions were favorable throughout early and middle Holocene (9,500-5,000-4,000), the Chinchorro put together a social and ideological system that was maintained until the mid-Holocene. Therefore, the development of a long-term "spiritscape", although framed by the ecological scenario, was certainly crafted within the ideological world, and it was transformed into a tradition that kept these groups together for several millennia. The meanings of this funerary ritual are unknown (Arriaza and Standen 2008; Marquet et al. 2012), but it is striking to note that despite all its variations, some basic principles were maintained within a confined territory between Ilo in the north and El Loa in the south (Figure 1), and this may have been their way to explain, represent, and show legitimacy to settle and claim particular territories for current and future generations (Ingold 2000; McNiven 2003; Pearson 2001).

Between 5,000 to 4,000 cal yrs BP the traditional habitat was transformed (resulting in lack of fresh water, changes in the variability and availability of marine-coastal resources). Population, however, was still growing and health conditions worsened as cases of infectious, metabolic and parasitic diseases increased as well as indicators of nutritional stress (Allison 1989). There is also an increase in occupational (external auditory exostosis), and degenerative diseases (osteoarthrosis) (Standen 1997). Competition for space seems to be reflected in death caused by interpersonal quarrel, especially among males (Standen and Arriaza 2000a).

In this rather unstable late phase of the Chinchorro tradition, individuals of all ages, including fetuses, were subject to highly complex AM, together with the red, bandage, and sand coated styles (Table 1). During the early period, mummification was applied principally to newborns or infants, while adults received low complex or no treatment at all. These transformations, such as the use of the red color, may be the result of the social dynamics that were taking place in that epoch as an attempt to maintain things as they used to be, looking to find new ways through and "keep on going" (Ingold 2011). The cultural transformation that took place while the composition and conditions of the environment were changing after 5,000 cal yrs BP seems not to have been sufficient. As a result, after 4,000 cal yrs BP the coastal peoples gradually abandoned their old traditions and shifted towards other forms of society and funerary rituals, linked to a mixed economy of marine hunting-gathering and horticulture (Núñez and Santoro 2011; Wise et al. 1994).

Acknowledgements: This paper was developed within the ECOS-CONICYT project: Dinámicas culturales en el Área Centro Sur Andina. Código C06H04 led by Teréssè Bouysse-Cassagne and Juan Chacama. Support for the research involved in this manuscript comes from different sources: Centro de Investigaciones del Hombre en el Desierto (CIHDE) CONICYT-REGIONAL R07C1001 to CS, FONDECYT projects 11070147, 1110582, National Geographic Research Grant \#8690-09, and FONDAP-FONDECYT 1501-0001 to MMR, and FONDECYT 1095006 to FR. Alex Alballay 
provided valuable help compiling the shell midden database and with GIS analyses. We are grateful to Paula Ugalde for her remarks, Marco Espinoza for English editing, Paola Salgado for improving the Figures, and the insightful comments by two anonymous reviewers of Chungara. The first reediting of the paper was finished in Dumbarton Oaks, August 2011, and it was edited at l'Université de Rennes 1 under the cadre de la Chaire des Amériques, Rennes 2, March-April 2012.

\section{References Cited}

Alfaro-Shigueto, J., J.C. Mange, M. Pajuelo, P.H. Dutton, J.A. Seminoff and B.J. Godley 2010. Where small can have a large impact: Structure and characterization of small-scale fisheries in Peru. Fisheries Research 106:8-17.

Allison, M. 1989. Condiciones de salud prehistóricas en el Norte Grande. In Culturas de Chile. Prehistoria, desde sus Orígenes hasta los Albores de la Conquista, edited by J. Hidalgo, V. Schiappacasse, H. Niemeyer, C. Aldunate and I. Solimano, pp. 221-226. Editorial Andrés Bello, Santiago.

Allison, M., B.T. Arriaza, V.G. Standen, G. Focacci, M.A. Rivera and J. Lowenstein 1984. Chinchorro, momias de preparación complicada: métodos de preparación. Chungara 13:155-174.

Andrus, C.F.T., Daniel H. Sandweiss and E.J. Reitz. 2008. Climate Change and Archaeology: The Holocene History of El Niño on the Coast of Peru. In Case Studies in Environmental Archaeology, 2nd Edition, edited by E. J. Reitz, C. M. Scarry and S. J. Scudder, pp. 143-157. Springer, New York.

Arriaza, B.T. 1994. Tipología de las momias Chinchorro y evolución de las prácticas de momificación. Chungara 26:11-47.

- - - 1995a. Beyond Death. The Chinchorro Mummies of Ancient Chile. Smithsonian Institution Press, Washington D.C.

- - - 1995b. Chinchorro Bioarchaeology: Chronology and Mummy Seriation. Latin American Antiquity 6:35-55.

- - - 2005. Arseniasis as an environmental hypothetical explanation for the origin of the oldest artificial mummification practice in the world. Chungara Revista de Antropología Chilena 37:255-260.

Arriaza, B.T., M. Allison, G. Focacci and E. Gerszten 1984. Mortalidad materna y de la niñez en el área de Arica Prehispánica y conceptos asociados. Chungara 12:161-172.

Arriaza, B.T., M. Allison and V.G. Standen 1984. Líneas de Harrris en una población Arcaica tardía del extremo norte de Chile: Morro-1. Chungara 13:187-193.

Arriaza, B.T., L. Cornejo, H. Lienqueo, V.G. Standen, C.M. Santoro, N. Guerra, J. Van Hoesen and M. Santos 2012. Caracterización química y mineralógica de los materiales grises de los cuerpos Chinchorro modelados. Chungara Revista de Antropología Chilena 44:177-194.

Arriaza, B.T., M. Doubrava, V.G. Standen and H. Haas 2005. Differential mortuary treatment among the Andean Chinchorro fishers: social inequalities or in situ regional cultural evolution? Current Anthropology 46:662-671.

Arriaza, B.T. and V.G. Standen 2002. Death, Mummies and Ancestral Rites: The Chinchorro Culture. Universidad de Tarapacá, Arica.
- - - 2008. Muerte, Momias y Ritos Ancestrales: La Cultura Chinchorro. Death, Mummies and Ancestral Rites: The Chinchorro Culture. Edición bilingüe. Editorial Universitaria, Santiago.

Arriaza, B.T., V.G. Standen, V. Cassman and C.M. Santoro 2008. Chinchorro Culture: Pioneers of the Coast of the Atacama Desert. Handbook of South American Archaeology. In Handbook of South American Archaeology, edited by H. Silverman and W.H. Isbell, pp. 45-58. Springer, New York.

Aufderheide, A.C. 2003. The Scientific Study of Mummified Human Remains. Cambridge University Press, Cambridge.

Aufderheide, A.C., I. Muñoz and B.T. Arriaza 1993. Seven Chinchorro mummies and the prehistory of northern Chile. American Journal of Physical Anthropology 91:189-201.

Aufderheide, A.C. and C. Rodríguez-Martín 1998. The Cambridge Encyclopedia of Human Paleopathology. Cambridge University Press, Cambridge.

Bird, J. 1943. Excavations in Northern Chile. American Museum of Natural History, New York.

Bittmann, B. 1982. Revisión del problema Chinchorro. Chungara 9:46-79.

Bittmann, B. and J. Munizaga 1976. The earliest artificial mummification in the world? A study of the Chinchorro complex in northern Chile. Folk 18:61-92.

- - - 1979. Algunas consideraciones en torno al complejo Chinchorro (Chile). In Actas del VII Congreso de Arqueología Chilena (1977), pp. 119-129. Kultrún, Santiago.

- - - 1980. Momificación artificial en el Pacífico Sur, ¿paralelismo o difusión? Indiana 6:381-398.

Boston, C.E. and B.T. Arriaza 2009. Arseniasis and teratogenic anomalies in the Atacama Desert coast of ancient Chile. Interciencia 34:338-343.

Byrne, S., D. Amarasiriwardena, B. Bandak, L. Bartkus, J. Kane, J. Joseph, J. Yañez, B. Arriaza and L. Cornejo 2010. Were Chinchorros exposed to arsenic? Arsenic determination in Chinchorro mummies' hair by laser ablation inductively coupled plasma-mass spectrometry (LA-ICP-MS). Microchemical Journal 94:28-35.

Chauchat, C. and J. Pelegrin 2003. Proyectil Point Technology and Economy. A Case Study from Paijan, North Coastal Perú: Pampa de Los Fosiles 14, Unit 1. Texas A\&M University, College Station.

Chazen, C.R., M.A. Altabet and T.D. Herbert 2009. Abrupt midHolocene onset of centennial-scale climate variability on the Peru-Chile Margin. Geophysical Research Letters 36:L18704. 
Craig, N. 2011. Cultural dynamics, climate, and landscape in the South-Central Andes during the mid-late Holocene: a consideration of two socio-natural perspectives. Chungara Revista de Antropología Chilena 43: 367-391.

de France, S. and A. Umire 2004. Arqueología Quebrada Tacahuay: un sitio marítimo del pleistoceno tardío en la costa sur del Perú. Chungara Revista de Antropología Chilena 36:257-278.

Debret, M., D. Sebag, X. Crosta, N. Massei, J.R. Petit, E. Chapron and V. Bout-Roumazeilles 2009. Evidence from wavelet analysis for a mid-Holocene transition in global climate forcing. Quaternary Science Reviews 28:2675-2688.

Delabarde, T., D. Lavallée, A. Bolaños and M. Julien 2009. Descubrimiento de un entierro del Arcaico Temprano en el sur del Perú. Bulletin de l'Institut Français d'Études Andines 38:939-946.

Dillehay, T.D. (ed) 2011. From Foraging to Farming in the Andes: New Perspectives on Food Production and Social Organization. Cambridge University Press, New York.

Dillehay, T.D., D. Bonavia, S.L. Goodbred Jr., M. Pino, V. Vásquez and T. Rosales Tham 2012. A late Pleistocene human presence at Huaca Prieta, Peru, and early Pacific coastal adaptations. Quaternary Research 77: 418-423.

Dillehay, T.D., J. Rossen, G. Maggard, K. Stackelbeck and P. Netherly 2003. Localization and possible social aggregation in the Late Pleistocene and Early Holocene on the north coast of Peru! Quaternary International 109-110 3-11.

Draper, P. 1973. Crowding among hunter-gatherers: The !Kung Bushmen. Science, New Series 182:301-303.

Drees, K.P., J.W. Neilson, J.L. Betancourt, J. Quade, D.A. Henderson, B.M. Pryor and R.M. Maier 2006. Bacterial community structure in the hyperarid core of the Atacama Desert, Chile. Applied and Environmental Microbiology 72:7902-7908.

Encinas, A., F. Hervé, R. Villa-MartÌnez, S.N. Nielsen, K.L. Finger and D.E. Peterson 2006. Finding of a Holocene marine layer in Algarrobo ( $33^{\circ} 22^{\prime} S$ ), central Chile. Implications for coastal uplift. Revista Geológica de Chile 33:339-345.

Flannery, K.V. 1986. Guilá Naquitz: Archaic Foraging and Early Agriculture in Oaxaca, Mexico. Academic Press, Orlando.

Gamble, C. 1999. The Palaeolithic Societies of Europe. Cambridge University Press, Cambridge.

Grosjean, M., L. Núñez and I. Cartajena 2005a. Cultural response to climate change in the Atacama Desert. In $23^{\circ}$ South: Archaeology and Environmental History of the Southern Deserts, edited by M. Smith and P. Hesse, pp. 156-171. National Museum of Australia Press, Canberra.

- - - 2005b. Palaeoindian occupation of the Atacama Desert, northern Chile. Journal of Quaternary Science 20:643-653.

Grosjean, M., C.M. Santoro, L. Thompson, L. Núñez and V.G. Standen 2007. Mid-Holocene climate and culture change in the south-central Andes. In Climate Change and Cultural Dynamics: A global Perspective on Mid-Holocene Transitions, edited by D. G. Anderson, K. A. Maasch and D. H. Sandweiss, pp. 51-115. Academic Press, New York.

Guillén, S. 2004. Artificial mummies from the Andes. Collegium Antropologicum 28:141-157.
Guillén, S.E. 1995. Morro V (Arica): momias y cráneos para discutir el origen y la naturaleza de la cultura Chinchorro. In Actas del XIII Congreso Nacional de Arqueología Chilena, pp. 55-64. Universidad de Antofagasta, Antofagasta.

Ingold, T. 2000 The Perception of the Environment: Essays on Livelihood, Dwelling and Skill. Routledge, London and New York.

- - - 2011. Being Alive: Essays on Movement, Knowledge and Description. Routledge, New York.

Isla, F.I., J.Q. Flory, C. Martinez, A. Fernandez and E. Jaque 2012. The Evolution of the Bio Bio delta and the coastal plains of the Arauco gulf, Bio Bio Region: the Holocene sea-level curve of Chile. Journal of Coastal Research 28:102-111.

Jackson, D., A. Maldonado, M. Carré and R. Seguel 2011. Huentelauquén cultural complex: the earliest peopling of the Pacific coast in the South-American southern cone. In Peuplement et Préhistoire en Amériques, edited by D. Vialou, pp. 221-231. Éditions du Comité des Travaux Historiques et Scientifiques, Paris.

Kaschner, K., J.S. Ready, E. Agbayani, J. Rius, K. Kesner-Reyes, P.D. Eastwood, A.B. South, S.O. Kullander, T. Rees, C.H. Close, R. Watson, D. Pauly and R. Froese 2008. AquaMaps Environmental Dataset: Half-Degree Cells Authority File (HCAF). World Wide Web electronic publication.

Knapp, B. and W. Ashmore 1999. Archaeological Landscape: Constructed, Conceptualized, Ideational. In Archaeologies of Landscape Contemporary Perspectives, edited by W. Ashmore and B. Knapp, pp. 1-30. Blackwell Publishers, Oxford.

Koerper, H.C. and J. Cramer 2011. A unique early discoidal from CA-ORA-85, Bolsa Chica Mesa. Pacific Coast Archaeological Society Quaterly 44:67-79.

Koerper, H.C., K. Reitz, S. Gust and S. Iverson 2006. A pattern recognition study of cogged stone ritual behavior. Proceedings of the Society for California Archaeology 19:120-127.

Latorre, C., J.L. Betancourt, J.A. Rech, J. Quade, C. Holmgren, C. Placzek, A. Maldonado, M. Vuille and K.A. Rylander 2005. Late Quaternary history of the Atacama Desert. In $23^{\circ} \mathrm{S}$ : The Archaeology and Environmental History of the Southern Deserts, edited by M. Smith and P. Hesse, pp. 73-90. National Museum of Australia Press, Canberra, Australia.

Latorre, C., A.L. González, J. Quade, J.M. Fariña, R. Pinto and P.A. Marquet 2011. Establishment and formation of fog-dependent Tillandsia landbeckii dunes in the Atacama Desert: Evidence from radiocarbon and stable isotopes. Journal of Geophysical Research 116 G03033.

Lavallée, D., P. Béarez, A. Chevalier, M. Julien, P. Usselmann and M. Fontugne 1999. Paleoambiente y ocupación prehistórica del litoral extremo sur del Perú. Las ocupaciones del arcaico en la quebrada de los Burros y alrededores (Tacna, Perú). Boletín de Arqueología PUCP 3:393-416.

Lavallée, D., M. Julien, P. Béarez, A. Bolaños, M. Carré, A. Chevalier, T. Delabarde, M. Fontugne, C. Rodríguez-Loredo, L. Klaric, P. Usselmann and M. Vanhaeren 2011. Quebrada de Los Burros. Los primeros pescadores del litoral Pacífico en el extremo sur peruano. Chungara Revista de Antropología Chilena 43:353-366.

Llagostera, A. 1982. Tres dimensiones en la conquista prehistórica del mar. In Actas del VIII Congreso de Arqueología Chilena, pp. 
217-245. Ediciones Kultrún, Sociedad Chilena de Arqueología, Universidad Austral de Chile, Valdivia.

- - - 1983. Formaciones pescadoras prehispánicas en la costa del Desierto de Atacama. Tesis Doctoral CIESAS, México.

- - - 1989. Caza y pesca marítima (9.000 - 1.000 a.C.). In Culturas de Chile. Prehistoria, desde sus Orígenes hasta los Albores de la Conquista, edited by J. Hidalgo, V. Schiappacasse, H. Niemeyer, C. Aldunate and I. Solimano, pp. 57-79. Editorial Andrés Bello, Santiago.

Llagostera, A., I. Kong and P. Iratchet 1997. Análisis ictioarqueológico del sitio La Chimba 13 (II Región, Chile). Chungara 29:163-180.

Manríquez, G., M. Moraga, C.M. Santoro, E. Aspillaga, B.T. Arriaza and F. Rothhammer 2011. Morphometric and mtDNA analyses of archaic skeletal remains from southwestern South America. Chungara Revista de Antropología Chilena 43:283-292.

Marquet, P.A., C.M. Santoro, C. Latorre, V.G. Standen, S.R. Abades, M.M. Rivadeneira, B. Arriaza and M.E. Hochberg 2012. Emergence of social complexity among coastal hunter-gatherers in the Atacama Desert of northern Chile. PNAS 109:14754-14760.

McNiven, I.J. 2003. Saltwater people: spiritscapes, maritime rituals and the archaeology of australian Indigenous seascapes. World Archaeology 35:329-349.

Mohtadi, M., O. Romero and D. Hebbeln 2004. Changing marine productivity off northern Chile during the past 19000 years: a multivariable approach. Journal of Quaternary Science 19:347-360.

Montecino, V. and C.B. Lange 2009. The Humboldt Current System: ecosystem components and processes, fisheries, and sediment studies. Progress in Oceanography 83:65-79.

Moy, C.M., G.O. Seltzer, D.T. Rodbell and D.M. Anderson 2002. Variability of El Niño/Southern Oscillation activity at millennial timescales during the Holocene epoch. Nature 420:162-165.

Munizaga, J. 1974. Deformación craneal y momificación en Chile. Anales de Antropología 11:329-336.

Nester, P.L., E. Gayo, C. Latorre, T.E. Jordan and N. Blanco 2007. Perennial stream discharge in the hyperarid Atacama Desert of northern Chile during the latest Pleistocene. Proceedings of the National Academy of Sciences of the United States of America 104:19724-19729.

Núñez, L. 1965. Recientes fechados radiocarbónicos del norte de Chile. Estudios Arqueológicos 1:107-109.

- - - 1966. Recientes fechados radiocarbónicos de la arqueología del norte de Chile. Boletín de la Universidad de Chile 64-65:32-41.

- - - 1969. El primer fechado radiocarbónico del complejo Faldas del Morro en el sitio Tarapacá-40 y algunas discuciones básicas. In Actas del V Congreso Nacional de Arqueología, pp. 47-58. Museo de Arqueología de La Serena, La Serena.

- - - 1975. Dinámica de grupos precerámicos en el perfil costaaltiplano, norte de Chile. Estudios Atacameños 3:59-74.

- - - 1986. Evidencias arcaicas de maíces y cuyes en Tiliviche: hacia el sedentarismo en el litoral fértil y quebradas del Norte de Chile. Chungara 16-17:25-49.

Núñez, L., M. Grosjean and I. Cartajena 2002. Human occupations and climate change in the Puna de Atacama, Chile. Science 298:821-824.
Núñez, L. and C. Moragas 1977-78. Ocupación Arcaica Temprana en Tiliviche, norte de Chile, I región. Boletín del Museo Arqueológico de La Serena 16:53-76.

Núñez, L. and C.M. Santoro 2011. El tránsito Arcaico-Formativo en la circumpuna y valles occidentales del Centro Sur Andino: hacia los cambios "neolíticos". Chungara Revista de Antropología Chilena 43:487-531.

Núñez, L. and J. Varela 1967. Sobre los recursos de agua y el poblamiento prehispánico de la costa del Norte Grande de Chile. Estudios Arqueológicos 3-4: 7-41.

Núñez, P. and V. Zlatar 1976. Radiometría de Aragón-1 y sus implicancias en el precerámico costero del norte de Chile. Actas y Memorias del IX Congreso Nacional de Arqueología Argentina.

Olmos, O. and J.A. Sanhueza 1984. El precerámico en la costa sur de Iquique. Chungara 13:143-154.

Ortlieb, L., G. Vargas and J.F. Saliege 2011. Marine radiocarbon reservoir effect along the northern Chile-southern Peru coast (14$\left.24^{\circ} \mathrm{S}\right)$ throughout the Holocene. Quaternary Research 75:91-103.

Pauketat, T.R. 2001. A New Tradition in Archaeology. In The Archaeology of Traditions, edited by T.R. Pauketat, pp. 1-16. University Press of Florida, Gainesville.

Pearson, M.P. 2001. The Archaeology of Death and Burial. Texas A\&M University Press, Texas.

Probst, P. 2002. Expansion and Enclosure: Ritual Landscapes and the Politics of Space in Central Malawi. Journal of Southern African Studies 28:179-198.

Rasmussen, K.A. 1998. Exploring the origin of coastal sedentism in the South-Central Andes. Ph.D. Thesis, Department of Anthropology, University of California, Santa Barbara.

Rech, J., J. Quade and J.L. Betancourt 2002. Late Quaternary paleohydrology of the Central Atacama Desert (22-24\%), Chile. Geological Society of America Bulletin 114:334-348.

Reinhard, K.J. and A.C. Aufderheide 1990. Diphyllobothriasis in prehistoric Chile and Peru: adaptive radiation of a helminth species to Native American populations. Paleopathol News 72:18-19.

Reinhard, K.J. and O. Urban 2003. Diagnosing ancient Diphyllobothriasis from Chinchorro Mummies. Mem Inst Oswaldo Cruz 98:191-193.

Rivadeneira, M., C.M. Santoro and P.A. Marquet 2010. Reconstructing the history of human impacts on coastal biodiversity in Chile: Constraints and opportunities. Aquatic Conservation: Marine and Freshwater Ecosystems 20:74-82.

Rivera, M.A. 1995. The preceramic Chinchorro mummy complex of northern Chile: context, style, and purpose. In Tombs for the Living: Andean Mortuary Practices, edited by T. D. Dillehay, pp. 43-77. Dumbarton Oaks Research Library and Collection, Washington, D.C.

Rothhammer, F. and T.D. Dillehay 2009. The late Pleistocene colonization of South America: an interdisciplinary perspective. Annals of Human Genetics 73:540-549.

Rothhammer, F., C.M. Santoro, E. Poulin, M. Moraga and V.G. Standen 2009. Archeological and mtDNA evidence for tropical lowland migrations and cultural change during the Late Archaic / Formative in northern Chile. Revista Chilena de Historia Natural 82:543-552. 
Ryan, W.B.F., S.M. Carbotte, J.O. Coplan, S. O'Hara, A. Melkonian, R. Arko, R.A. Weissel, V. Ferrini, A. Goodwillie and F. Nitsche 2009. Global multi-resolution topography synthesis. Geochemistry Geophysics Geosystems 10:Q03014.

Sandweiss, D.H. 2003. Terminal Pleistocene through MidHolocene archaeological sites as paleoclimatic archives for the Peruvian coast. Palaeogeography, Palaeoclimatology, Palaeoecology 194:23-40.

Sandweiss, D.H., K.A. Maasch, R.L. Burger, J.B. Richardson, H.B. Rollins and A. Clement 2001. Variation in Holocene El Nino frequencies: Climate records and cultural consequences in ancient Peru. Geology 29:603-606.

Sandweiss, D.H., H. McInnis, R.L. Burger, A. Cano, B. Ojeda, R. Paredes, M. Sandweiss and M. Glascock 1998. Quebrada Jaguay: Early south American maritime adaptations. Science 281:1830-1832.

Santoro, C.M., C. Latorre, C. Salas, D. Osorio, P. Ugalde, D. Jackson and E.M. Gayó 2011. Ocupación humana pleistocénica en el Desierto de Atacama. Primeros resultados de la aplicación de un modelo predictivo interdisciplinario. Chungara Revista de Antropología Chilena 43:353-366.

Santoro, C.M., V.G. Standen, B.T. Arriaza and T.D. Dillehay 2005. Andean Archaic funerary pattern or postdepositional alteration? The Patapatane burial in the highlands of South Central Andes. Latin American Antiquity 16:329-346.

Santoro, C.M., V.G. Standen, B.T. Arriaza and F. Rothhammer 2010. El legado de Max Uhle en la arqueología de Arica. In Max Uhle (1856-1944) Evaluaciones de sus Investigaciones y Obras, edited by P. Kaulicke and M. Fischer, pp. 349-357. Fondo Editorial de la Pontificia Universidad Católica del Perú, Lima.

Schiappacasse, V. 1995. Utilidad del análisis comparativo del desecho lítico de varios sitios arcaicos de la Quebrada de Camarones. In Actas del XIII Congreso Nacional de Arqueología Chilena, pp. 29-34. Universidad de Antofagasta, Antofagasta.

Schiappacasse, V. and H. Niemeyer 1975. Apuntes para el estudio de la transhumancia en el valle de Camarones (provincia de Tarapacá, Chile). Estudios Atacameños 3:49-52.

- - - 1984. Descripción y Análisis Interpretativo de un Sitio Arcaico Temprano en la Quebrada de Camarones. Publicación Ocasional del Museo Nacional de Historia Natural, Santiago.

SERNAPESCA 1999-2005. Anuario Estadístico de Pesca. SERNAPESCA, Santiago.

Skottsberg, C. 1924. Notes on the old indian necropolis of Arica. Meddelanden Fran Geografiska Föreningen i Göteborg 3:27-78.

Standen, V.G. 1991. El Cementerio Morro 1: Nuevas Evidencias de la Tradición Funeraria Chinchorro (Período Arcaico, Norte de Chile). Tesis Maestría Pontificia Universidad Católica de Perú, Lima.

- - - 1997. Temprana Complejidad Funeraria de la Cultura Chinchorro (Norte de Chile). Latin American Antiquity 8:134-156.

- - - 2003. Bienes funerarios del cementerio Chinchorro Morro 1: descripción, análisis e interpretación. Chungara, Revista de Antropología Chilena 35:175-207.

- - - 2011. Violencia y Cultura en Cazadores, Pescadores y Recolectores Chinchorro de la Costa del Desierto de Atacama, Norte de Chile (8900-3700 años A.P.). Tesis Doctoral Departamento de Antropología, Universidad Nacional Autónoma de México, Mexico DF.

Standen, V.G., M. Allison and B.T. Arriaza. 1984. Patologías óseas de la población Morro-1, asociada al complejo Chinchorro: norte de Chile. Chungara 13:175-185.

Standen, V.G. and B.T. Arriaza. 1999. Traumas en las poblaciones Chinchorro (costa norte de Chile): ¿violencia o situaciones accidentales? Chungara 29:133-150.

- - - 2000a. La treponematosis (yaws) en las poblaciones prehispánicas del desierto de Atacama (norte de Chile). Chungara, Revista de Antropología Chilena 32:185-192.

- - - 2000b. Trauma in the preceramic coastal populations of northern Chile: violence or occupational hazards? American Journal of Physical Anthropology 112:239-249.

Standen, V.G., B.T. Arriaza and C.M. Santoro 1997. External auditory exostosis in prehistoric Chilean populations: a test of chronology and geographic distribution. American Journal of Physical Anthropology 103:119-129.

Standen, V.G. and C.M. Santoro 2004. Patrón funerario arcaico temprano del sitio Acha-3 y su relación con Chinchorro: Cazadores, pescadores y recolectores de la costa norte de Chile. Latin American Antiquity 15:89-109.

Standen, V.G., C.M. Santoro and B.T. Arriaza 2004. Síntesis y propuesta para el período Arcaico en la costa del extremo norte de Chile. Chungara Volumen Especial:201-212.

Steele, J., C. Gamble and T. Sluckin 2000. Estimating the rate of Paleoindian expansion into South America. In People as Agents of Environmental Change, edited by T.O. Connor and R. Nicholson, pp. 125 - 133. Oxbow Books, Oxford.

Steele, J. and G.G. Politis 2009. AMS 14C dating of early human occupation of southern South America. Journal of Archaeological Science 36:419-429.

Stothert, K.E., D.R. Piperno and T.C. Andres 2003. Terminal Pleistocene/early Holocene human adaptation in coastal Ecuador: the Las Vegas evidence. Quaternary International 109-110:23-43.

Thiel, M., E.C. Macaya, E. Acuna, W.E. Arntz, H. Bastias, K. Brokordt, P.A. Camus, J.C. Castilla, L.R. Castro, M. Cortes, C.P. Dumont, R. Escribano, M. Fernandez, J.A. Gajardo, C.F. Gaymer, I. Gomez, A.E. Gonzalez, H.E. Gonzalez, P.A. Haye, J.E. Illanes, J.L. Iriarte, D.A. Lancellotti, G. LunaJorquerai, C. Luxoroi, P.H. Manriquez, V. Marin, P. Munoz, S.A. Navarrete, E. Perez, E. Poulin, J. Sellanes, H.H. Sepulveda, W. Stotz, F. Tala, A. Thomas, C.A. Vargas, J.A. Vasquez and J.M.A. Vega 2007. The Humboldt Current System of northern and central Chile. Oceanography and Marine Biology, Vol 45 45: 195-344. Oceanography and Marine Biology 45:195-344.

True, D.L. and L. Núñez 1972. Modeled anthropomorphic figurines from northern Chile. Nawpa Pacha 9:65-91.

Uhle, M. 1917. Los aborígenes de Arica. Publicaciones del Museo de Etnología y Antropología de Chile 1:151-176.

- - - 1919a. Fundamentos étnicos de la región de Arica y Tacna. Boletín de la Sociedad Ecuatoriana de Estudios Históricos Americanos 2:1-37.

- - - 1919b. La arqueología de Arica y Tacna. Boletín de la Sociedad Ecuatoriana de Estudios Históricos Americanos 3:1-48. 
- - - 1922. Fundamentos étnicos de la región de Arica y Tacna Boletín de la Sociedad Ecuatoriana de Estudios Históricos Americanos II(4).

- - - 1974. Los aborígenes de Arica y el hombre americano. Chungara 3:13-21.

Umire, A.O. 2009. Yara: Frontera Norte de la Complejidad Funeraria Chinchorro. Tesis Maestría, Departamento de Antropología e Instituto de Investigaciones Arqueológicas y Museo, Universidad de Tarapacá y Universidad Católica del Norte, Arica.

Van Hoesen, J. and Bernardo T. Arriaza 2011. Characterizing the micromorphology of sediments associated with Chinchorro mummification in Arica, Chile using SEM and EDS. Archaeometry 53:986-995.

Waelbroeck, C., L. Labeyrie, E. Michel, J.C. Duplessy, J. McManus, K. Lambeck, E. Balbon and M. Labracherie 2002. Sea-level and deep water temperature changes derived from benthic foraminifera isotopic records. Quaternary Science Reviews 21:295-230.

Wells, L. and J.S. Noller 1999. Holocene coevolution of the physical landscape and human settlement in northern coastal Peru. Geoarcheology: an International Journal 14:755-789.
Williams, A., C.M. Santoro, M.A. Smith and C. Latorre 2008. The impact of ENSO in the Atacama desert and Australian arid zone: exploratory time-series analysis of archaeological records. Chungara, Revista de Antropología Chilena 40:245-259.

Winterhalder, B. 1993. Work, resources and population in foraging societies. Man, New Series 28:321-340.

Wise, K. 1990. Late Archaic maritime subsistence strategies in the South Central Andes. Ph.D. Thesis, Department of Anthropology, Northwestern University.

- - - 1995. La ocupación Chinchorro en Villa del Mar, Ilo, Perú. Gaceta Arqueológica Andina 24:135-149.

- - - 1997. The Late Archaic period occupation at Carrizal, Peru. Contributions in Science 467:1-16.

- - - 1999. El periodo Arcaico en el Perú: hacia una definición de los orígenes. Boletín de Arqueología Pontificia Universidad Católica de Perú 3:335-363.

Wise, K., N.R. Clark and S.R. Williams 1994. A Late Archaic Period Burial from the South-Central Andean Coast. Latin American Antiquity 5:212-227. 
